\title{
Does the Equity Market Reward "Superior" Management Earnings Forecast? Evidence from the U.S. Quarterly Earnings Guidance
}

\author{
Tina Wang \\ University of Texas, USA
}

\begin{abstract}
This paper examines whether equity markets reward the controversial practice of issuing short-term management earnings forecasts. Using a large sample of quarterly earnings forecasts, this research found that firms may temporarily reduce stock price volatility by issuing quarterly earnings forecasts. Furthermore, the analysis showed that not all guidance issuers are equally rewarded by equity capital markets. The benefits of reduced stock price volatility and favorable market valuation primarily accrue to firms with a track record of supplying accurate and timely short-term earnings forecasts. Findings suggest that superior short-term earnings guidance, which fosters transparent financial information environments and reduces investor information uncertainty, is indeed rewarded by equity capital markets. As limited research examines the association between forecast attributes and the capital market consequences of quarterly earnings guidance, this study aimed to provide empirical evidence on equity capital market rewards by issuing high-quality quarterly earnings guidance. A practical implication is that firms need to invest in accounting information systems and accounting talent in order to achieve capital market benefits of supplying high-quality short-term earnings forecasts.
\end{abstract}

Keywords: quarterly earnings guidance, forecast attributes, accounting information system, equity market rewards, United States

\section{$\underline{\text { ARTICLE INFO }}$}

Article History:

Received: 30 December 2020

Accepted: 6 June 2021

Published: 1 December 2021

- Corresponding Author: Tina Wang. Email: acctxtw2014@gmail.com 


\section{INTRODUCTION}

Management earnings forecasts are attributable to firms' internal budgeting/ performance evaluation systems and the external use of management earnings forecasts is widely viewed as merely a by-product of this process (Kato, Skinner, \& Kunimura, 2009). In the United States, a large number of publicly traded companies voluntarily issue annual or quarterly management earnings forecasts to provide timely financial information to capital market participants. This study empirically examined the capital market benefits of quarterly earnings guidance, a voluntary disclosure practice in the United States. The practice of providing short-term earnings guidance (e.g., quarterly earnings per share) has generated heated debate in the business and investor communities. Many opponents believe that such voluntary disclosure practice encourages an excessive focus on short-term results and shifts management's attention away from long-term value creation. The most obvious cost of issuing quarterly earnings guidance is the lost time of corporate managers, who would rather focus on strategic plans and business development than worry about how to avoid missing their own earnings forecasts quarter by quarter. Guidance issuers may also incur reputation costs and capital market penalties if they fail to meet their earnings targets.

Despite the criticism of short-term guidance, most companies have only made marginal changes in their guidance practice (Deloitte, 2009). A significant number of firms still follow the practice of issuing quarterly earnings guidance. Many corporate managers believe that the issuance of quarterly earnings guidance helps firms build a reputation for transparent financial reporting, which lowers information uncertainty and reduces share price volatility. As a result, guidance issuers should enjoy the benefits of reduced stock return volatility and favorable market valuation. Despite such claims, little academic research has been devoted to the bright side of issuing short-term earnings guidance. The first objective of this study was to provide empirical evidence on whether short-term guidance issuers achieve the benefits of reduced share price volatility and higher market valuation.

The second research objective was to investigate whether "superior" forecasters benefit differentially from the issuance of short-term management earnings guidance than other guidance issuers. Psychology research finds that source credibility influences individuals' judgment and 
decision making. Communications from more credible sources not only receive greater weight from the audience (e.g., Beach, Mitchell, Deaton, \& Prothero, 1978; Birnbaum, Wong, \& Wong, 1976), but also influence the audience's confidence judgments (e.g., Settle \& Golden, 1974; Hinsz, Tindale, Nagao, Davis, \& Robertson, 1988). Confidence is defined as a measure of an individual's uncertainty (Kahneman \& Tversky, 1982). In the management earnings forecast context, superior guidance issuers are believed to have greater ability to alleviate investors' information uncertainty regarding firms' economic fundamentals. Consequently, researchers should observe considerable cross-sectional variations in capital market rewards to short-term earnings guidance.

To achieve the first research objective, this study constructed a propensity-score matched sample to test whether short-term guidance issuers exhibit reduced price volatility and favorable valuation. The propensity-score matched sample design allowed for better control for the self-selection bias associated with the issuance of short-term guidance. Using sample firms that supply quarterly earnings forecasts and a propensityscore matched control sample, this study revealed that firms issuing shortterm guidance exhibit lower stock return volatility over the six-month measurement window following the release of earnings guidance. Over longer measurement windows, there were no significant differences in stock price volatility between short-term guidance issuers and their non-issuer counterparts. Furthermore, there is no evidence that short-term guidance issuers exhibit favorable market valuation compared to their non-issuer counterparts. Thus, these results suggest that limited benefits accrue to short-term guidance issuers.

To test the second research objective, short-term guidance issuers were classified into two groups: superior guiders and other guidance issuers. "Superior guidance issuers" refer to firms that provide accurate and timely quarterly earnings-per-share (EPS) forecasts on a regular basis. Superior guidance issuers were identified based on four forecast attributes: accuracy, timeliness, regularity, and consistency. In this research setting, accuracy refers to the magnitude of difference between the forecast and actual EPS. Regularity refers to the number of unique quarters over a fourquarter measurement window in which the firm issues at least one quarterly earnings forecast. Prior research suggests that stock price reaction to good 
news is larger for firms with a reputation for issuing accurate and frequent forecasts (Hutton \& Stocken, 2009). Forecasting firms with higher prior forecast accuracy lead to greater earnings forecast revisions by analysts (Williams, 1996). Thus, accuracy and regularity should be viewed as desirable forecast characteristics. In today's fast-moving capital markets, information is viewed as more useful for investor decision making if it is released quickly. Thus, timeliness is a superior forecast attribute. Timeliness in this setting specifically refers to the difference in time between the relese of the forecast and the actual earnings realization (Waymire, 1985). If a firm can consistently deliver earnings (i.e., meet or beat its own forecast earnings target), it will be viewed as stable and well run. Thus, "consistency" is a desirable forecast attribute. Consistency refers to the number of unique quarters over the measurement window of the current and prior three quarters in which the firm meets or beats its own EPS forecast.

The second set of tests found that issuers with a track record of issuing accurate and timely EPS forecasts on a regular basis exhibit lower stock return volatility. Furthermore, the second set of tests reveal that the benefits of reduced volatility accrued to superior guidance issuers extend to much longer windows. This study also found that firms with a history of regularly providing timely and accurate quarterly earnings forecasts are rewarded by the market in the form of higher price-to-earnings $(\mathrm{P} / \mathrm{E})$ multiples. However, there is little evidence that, among short-term guidance issuers, firms consistently meeting or beating their EPS targets are valued more favorably by investors.

Taken together, this study showed that firms which merely issue short-term earnings guidance receive limited capital market benefits in the form of reduced stock price volatility. This benefit, however, is short run, lasting only one to two quarters. Firms with a track record of issuing accurate and timely quarterly earnings forecasts on a regular basis are rewarded by investors in the form of reduced stock return volatility and favorable valuation. These findings support the notion that equity markets reward superior short-term guidance issuers, firms that have developed a reputation for providing transparent financial information to business and investor communities. 
Documenting the long-term capital market benefits of short-term earnings guidance contributes to the management earnings forecast research in several ways. First, despite investors' great demand for forward-looking information, conflicting views exist regarding the practice of issuing quarterly earnings forecasts. On the one hand, a few large firms, like CocaCola, AT\&T, General Electric, and McDonald's, have stopped issuing quarterly earnings guidance. Executives of these companies believe that the decision has changed their focus from the short term to the long term fairly dramatically. One the other hand, many corporate managers still view the practice of issuing short-term earnings guidance positively (Deloitte, 2009; $\mathrm{Kim}, \mathrm{Su}, \mathrm{Z} \mathrm{Zhu}, 2016)$. This study offers an explanation for the continuance of the controversial practice of issuing short-term earnings guidance. By providing high-quality voluntary disclosures including quarterly earnings forecasts, firms build a reputation for being transparent with financial information and reduce information uncertainty about firm performance. This study confirmed the conjectured benefits of lower share price volatility and higher market valuation accrued to superior short-term guidance issuers.

Second, there is no one-size-fits-all solution when it comes to communicating forward-looking information to the investor and analyst communities. Documenting the cross-sectional variation in the practice of providing short-term earnings guidance and the resulting benefits should provide useful information to corporate managers who are debating whether to continue the costly practice of issuing such guidance. For those firms that continue to supply quarterly earnings forecasts, these findings highlight desirable characteristics that management earnings forecasts should possess. A practical implication for corporate managers is to invest in accounting information systems and accounting talent to improve the quality of management earnings forecasts.

This study also offers insights into managers' forecast choices once they decide to issue earnings forecasts, an area less understood in the management earnings forecast literature (Hirst, Koonce, \& Venkataraman, 2008). Existing research on capital market consequences of management earnings forecasts mainly focuses on short-term market reactions to such forecasts (Atiase, Li, Supattarakul, \& Tse 2005; Yang, 2012). This study not only confirms and complements prior experimental findings that forecast credibility influences investor judgment, but also fills the void 
in the literature by providing large-sample archival evidence on the longterm capital market effects (i.e., price volatility and market valuation) of issuing high-quality management earnings forecasts (Hirst, Koonce, \& Miller, 1999).

\section{LITERATURE REIVEW AND HYPOTHESIS DEVELOPMENT}

\section{Research on Short-Term Earnings Guidance}

The practice of issuing management earnings forecasts exhibits significant cross-country differences due to the diverse institution factors developed in different jurisdictions (e.g., Kato, Skinner, \& Kunimura, 2009; Li, Ng, Tsang, \& Urcan, 2021; Guan, Lobo, Tsang, \& Xin, 2021). U.S. publicly traded companies are required by the Security Exchange Commission (SEC) to file three interim financial reports shortly after the end of $1^{\text {st }}, 2^{\text {nd }}$, and $3^{\text {rd }}$ quarters. A significant number of firms also voluntarily issue quarterly earnings per share forecasts in press releases to guide financial analysts and other capital market participants (e.g., Williams, 1996; Kim, Kim, \& Lee, 2021; Kim, Su, \& Zhu, 2016). High-quality voluntary disclosures, including management earnings forecasts, help publicly traded companies develop a reputation for transparent financial reporting. The practice of issuing quarterly earnings guidance, however, is quite controversial. Many believe that such practice encourages excessive focus on short-term results and shifts management's attention away from long-term value creation.

Despite the widespread criticism over short-term earnings guidance, business surveys and academic research reveal that many publicly traded companies still follow this practice (e.g., Kim, Su, \& Zhu, 2016). Chen, Matsumoto, and Rajgopal (2011) researched press releases and conference call transcripts and they identified only 72 firms that stopped issuing quarterly earnings guidance. The 2010 survey released by National Investor Relations Institute (NIRI) shows that approximately $76 \%$ of its members provide financial guidance and, of those, $37 \%$ issue quarterly earnings guidance. To provide insights into this controversial practice, this study conducted an empirical analysis of firms issuing quarterly earnings guidance 
and explored whether equity markets reward the provision of short-term earnings forecasts.

Although a large accounting literature has examined management earnings forecasts (Hirst, Koonce, \& Venkataraman, 2008), limited academic research studies quarterly earnings guidance. Houston, Lev, and Tucker (2010) and Chen, Matsumoto, and Rajgopal (2011) examined firms that stopped issuing quarterly earnings forecasts. Both studies revealed that firms stopped issuing quarterly earnings guidance primarily due to poor performance; further, these two studies provide some evidence on deterioration in guidance stoppers' information environment. Houston et al. (2010) found no evidence that guidance stoppers subsequently provide alternative high-quality disclosures or increase in long-term investments. $\mathrm{Kim}, \mathrm{Su}$, and Zhu (2016), another study on the economic consequences of cessation of short-term earnings guidance, documented that short-term guidance stoppers attract more long-term institutional investors.

Call, Chen, Miao, and Tong (2014) examined the effect of issuing quarterly earnings guidance on earnings management. Contrary to the concerns expressed by some investor communities, firms issuing shortterm earnings forecasts exhibit less rather than more accrual-based earnings management. Further, they document that firms regularly issuing short-term earnings guidance exhibited the least accrual-based earnings management. In sum, the limited academic research on quarterly earnings forecasts yielded little support for "hypothesized costs" associated with this controversial practice. Similar to Hilary, Hsu, Segal, and Wang (2016), which studied the bright side of issuing optimistically biased management earnings forecasts rather than negative consequences, this study filled the research gap by examining the long-term capital market benefits derived from issuing short-term earnings guidance. Specifically, this study explored whether stock markets reward short-term guidance issuers in the form of reduced price volatility and favorable valuation.

\section{Superior Management Earnings Forecast and Idiosyncratic Return Volatility}

Existing finance and accounting literature documents both significant cross-sectional variations and upward trends in idiosyncratic return volatility 
over the past several decades (Campbell, Lettau, Malkiel, \& Xu, 2001). Increased stock price volatility stems from investor uncertainty about a firm's future performance, which is attributable to either volatility of a firm's economic performance or inferior information about firm performance or both. Prior research demonstrates that the availability of public accounting information is negatively associated with stock return volatility (Mock, Yeung, \& Yu, 2000; Jin \& Myers, 2006). Earnings are the most important performance metrics, closely followed by equity investors (Ohlson, 1995, Higashikawa, 2021). The practice of issuing quarterly earnings forecast increases the amount of publicly available financial information, which improves a firm's information environment and thus decreases investor uncertainty about future economic performance (Chen, Matsumoto, \& Rajgopal, 2011).

As a financial executive of an internet-based retail company put it: "We provide quarterly earnings guidance because I'm more likely to be more accurate than the analysts given the significantly greater visibility I have into my own business at any given time. They cover too many companies and can't spend the time to develop a detailed estimate for my company. The obvious downside when they get it wrong is increased volatility" (Deloitte, 2009). The above argument led to the first hypothesis:

$\mathbf{H}_{\mathbf{1}}$ : Stock return volatility is negatively associated with the issuance of short-term earnings guidance.

The quality of public financial information exhibits significant cross-sectional variation. High-quality financial reporting provides more firm-specific information to capital markets and improves investor decisionmaking. Opaque financial reporting, however, is less informative about firmspecific performance, causing ambiguity about underlying firm performance among capital market participants and increasing price volatility and crash risks (i.e., Hutton, Marcus, \& Tehranian, 2009; Rajgopal \& Venkatachalam, 2011). Likewise, the quality of management earnings forecast also exhibits significant variation. Research in management earnings forecasts reveals that capital market participants generally view accuracy as a more desirable forecast attribute (Williams, 1996; Hirst, Koonce, \& Venkataraman, 2008). Accurate earnings forecasts convey more credible information to the capital markets; analysts and investors react more strongly to earnings forecasts 
issued by firms with a history of providing accurate earnings forecasts (Williams, 1996; Hutton \& Stockton, 2009).

It is a difficult task to predict earnings in an increasingly competitive and volatile economic environment. The provision of high-quality earnings guidance, to a large extent, depends on the combination of a talented management team, the state-of-the-art information systems, and efficient financial reporting processes (Feng, Li, \& McVay, 2009; Yang, 2012). Firms that regularly issue quarterly earnings guidance are more likely to make costly investments in financial talent, technology, and processes to improve the quality of management earnings forecasts. A direct implication of this argument is that earnings forecasts issued by regular guiders better reflect future performance and thus alleviate investor uncertainty about a firm's economic fundamentals. Regularity should be viewed as a desirable attribute of quarterly earnings forecasts.

Surveys with financial executives reveal a significant increase in investor uncertainty about future performance when firms fail to meet earnings targets (Graham, Harvey, \& Rajgopal, 2005). If a firm repeatedly misses its own earnings guidance, investors not only cast doubt over the firm's prospects in the next few quarters but also suspect that the firm has previously unknown and deeper problems. A history of failing to meet its own forecasts could be a manifestation of the firm's economic fundamentals or a direct result of the firm's dysfunctional financial reporting processes or a combination of multiple factors. Conversely, if a firm consistently delivers earnings (i.e., meeting or exceeding the guided numbers), it will be viewed as "well-run and stable," implying less uncertainty about firm performance as well as less information risks. Consequently, a record of consistently meeting its own guided numbers, consistency is another important dimension of "superiority" of earnings guidance.

In today's fast-moving capital markets, financial information must be released quickly if it is to be useful in supporting investors' decision-making. Thus, timeliness should be a desirable attribute of financial information. In the context of quarterly management earnings guidance, timeliness specifically refers to the difference in time between the forecast release date and the actual earnings realization (Hirst, Koonce, \& Venkataraman, 2008). More timely forecasts are issued further in advance of the forecasted 
fiscal quarter ending date. If a firm releases quarterly earnings forecasts on a timelier basis, it will be viewed as more efficient and effective in managing its business and risks, which, may enhance investors' confidence in its operation and management. Consequently, timely issuers should exhibit reduced stock price volatility. The above arguments led to the second hypothesis:

$\mathbf{H}_{2}$ : Superior" short-term guidance issuers exhibit reduced stock return volatility.

\section{Superior Management Earnings Forecasts and Stock Valuation}

The next inquiry was motivated by a belief held by many corporate managers: the practice of issuing quarterly earnings guidance results in higher stock valuation. The Disclosure Theory reveals that the issuance of management earnings forecasts, especially high-quality management earnings forecasts, could be an indicator of superior managerial ability (Trueman, 1986). Management earnings forecasts are attributable to a firm's internal budgeting/performance evaluation system; their use as external forecasts is merely a by-product of this process (e.g., Kato, Skinner, \& Kunimura, 2009). Consistent with this view, Hilary, Hsu, Segal, and Wang (2016) revealed that even optimistically biased forecasts can motivate mangers to exert greater efforts and improve firm profitability. As forecasting skills are central to many business decisions, corporate managers who are able to provide superior management earnings guidance are more likely to make better day-to-day decisions such as cost control and strategic decisions like business acquisitions (e.g., Goodman, Neamtiu, Shroff, \& White, 2014; Yasukata, 2013). Consequently, investors may perceive firms that issue superior management earnings guidance as being well run and having a greater ability to generate cash flows.

Furthermore, the issuance of management earnings forecasts, especially high-quality management earnings forecasts, could reduce information uncertainty about firm economic fundamentals. Such firms may appear less risky to outside investors; investors, in turn, may demand lower risk premiums due to lower perceived information risks (e.g., Baginski \& Rakow, 2012; Cao, Myers, Tsang, \& Yang, 2017). Valuation models such 
as discounted cash flows model and residual income model reveal that firm value depends on both earnings/operating cash flows and discount rate. Firms issuing superior management earnings guidance may claim higher market valuation if investors believe that such firms have better cash flow prospects or require lower discount rates due to lower information risks. The above arguments led to the second set of hypotheses:

$\mathbf{H}_{3}$ : Firms issuing short-term earnings guidance exhibit higher market valuation.

$\mathbf{H}_{4}$ : "Superior" short-term earnings guidance issuers exhibit higher market valuation.

\section{RESEARCH DESIGN}

\section{Sample}

This study carefully constructed two samples to empirically address the research questions. First, the study constructed a sample of firms that provide quarterly EPS forecasts over the period of 2001 to 2009 from First Call's Company Issued Guidance (CIG) database. Financial data were from COMPUSTAT, while stock price and stock return data were from CRSP. The sample started from year 2001 because the adoption of Regulation FD on August 15, 2000 had fundamentally changed the disclosure practice of publicly traded companies, which has had a significant impact on firms' information environments. The sample ended in year 2009 because CIG data was discontinued in early 2010s by the issuer First Call. The termination of data collection by First Call reflects limited market demand - only a handful of accounting research heavy schools subscribe this dataset. The constructed sample included firms that issued point or range forecasts to construct a meaningful measure of forecast accuracy, which is an important attribute of management earnings forecasts. Further, for firms that issued multiple EPS guidance for the same quarter, only the first issued guidance was included in the sample to construct a meaningful measure of timeliness. To eliminate earnings pre-announcements, the guidance issuers sample excluded forecasts issued after the corresponding fiscal quarter ending dates. Next, a propensityscore-matched control sample was constructed based on observable firm characteristics that existing literature had identified as associated with the 
issuance of management earnings guidance. The provision of management earnings forecasts is voluntary; thus, firms that issue short-term earnings guidance could be significantly different than firms that do not guide. The propensity-score-matched procedure mitigates the concern that differences in the relation between capital market consequences and the issuance of quarterly earnings guidance are driven by other firm characteristics rather than the issuance of earnings guidance (The details of the construction of the propensity-score-matched sample is available upon request). The issuer sample and the control sample were employed to test hypotheses $\mathrm{H} 1$ and $\mathrm{H} 3$. Hypotheses $\mathrm{H} 2$ and $\mathrm{H} 4$ were tested based on the guidance issuer sample.

Table 1: Descriptive Statistics

\begin{tabular}{lccccc}
\hline \multicolumn{1}{r}{ Variable } & Mean & Median & Q1 & Q3 & Std. Dev. \\
\hline MF & 0.500 & 0.500 & 0.000 & 1.000 & 0.500 \\
TACC & 0.047 & 0.032 & 0.014 & 0.062 & 0.051 \\
STD_CFO & 0.055 & 0.047 & 0.033 & 0.066 & 0.037 \\
CFO & 0.058 & 0.050 & 0.015 & 0.099 & 0.081 \\
SIZE & 4,121 & 909 & 341 & 2,975 & 9,461 \\
BM & 0.467 & 0.388 & 0.248 & 0.599 & 0.334 \\
LEVERAGE & 0.466 & 0.465 & 0.287 & 0.614 & 0.226 \\
NUM_ANAL & 8 & 7 & 4 & 11 & 5.917 \\
INSTPCT & 0.726 & 0.771 & 0.593 & 0.897 & 0.246 \\
NI & 0.345 & 0.280 & 0.090 & 0.053 & 0.422 \\
BVE & 10.716 & 9.038 & 5.212 & 14.359 & 7.770 \\
BVEGROWTH & 0.171 & 0.105 & -0.008 & 0.234 & 0.598 \\
DE & 0.491 & 0.222 & 0.000 & 0.629 & 1.045 \\
RET3M & 0.037 & 0.041 & -0.074 & 0.155 & 0.220 \\
RET6M & 0.076 & 0.079 & -0.084 & 0.241 & 0.314 \\
RET12M & 0.152 & 0.154 & 073 & 0.383 & 0.434 \\
RET24M & 0.316 & 0.302 & 0.013 & 0.617 & 0.551 \\
VOL3M ${ }^{* 1000}$ & 24.559 & 21.179 & 15.247 & 29.789 & 13.611 \\
VOL6M ${ }^{* 1000}$ & 24.834 & 21.597 & 15.945 & 29.810 & 13.206 \\
VOL12M ${ }^{*} 1000$ & 25.082 & 21.947 & 16.385 & 29.900 & 13.040 \\
VOL24M ${ }^{* 1000}$ & 25.225 & 22.292 & 16.774 & 29.948 & 12.589 \\
PRICE & 28.301 & 24.210 & 13.700 & 38.180 & 19.592 \\
P/E & 84 & 72 & 45 & 111 & 268 \\
\hline SE & & & & & \\
\hline
\end{tabular}

See the Appendix for variable definition

Table 1 provides statistics of the full sample, which consisted of 31,650 observations of firms issuing quarterly earnings guidance and 
non-issuing control firms. The mean (median) value of total assets (SIZE) of sample firms was approximately $\$ 4,121$ million ( $\$ 908$ million). The mean and the median values of book-to-market ratio $(B M)$ are 0.47 and 0.39 . The average (median) sample firm was covered by approximately 8 (7) analysts; the mean (median) institutional ownership (INSTPCT) was $73 \%(77 \%)$. The mean (median) value of debt-to-equity ratio $(D E)$ was $0.49(0.22)$. The mean (median) value of earnings per share $(N I)$ is 0.35 (0.28). The mean (median) firm was priced (PRICE) at \$28.30 (\$24.21) per share. The average buy-and-hold returns (RET) over the 3-month window, 6-month window, 12-month window, and 24-month window were $3.7 \%$, $7.6 \%, 15.2 \%$, and $31.6 \%$, respectively. The median values of buy-and-hold returns over various measurement windows were similar to the mean values. The mean (median) value of return volatility $(V O L)$ over the three-month measurement window was 0.025 (0.021). The mean (median) values of return volatility over other measurement windows were similar to those over the three-month measurement window. Untabulated results revealed that guidance issuers exhibited similar firm characteristics relative to their non-issuer counterparts.

\section{Regression Model for Hypotheses H1 and H2}

The study estimated regression model (1) to test the effect of quarterly earnings guidance on stock return volatility:

$$
\begin{aligned}
\mathrm{VOL}= & \beta_{0}+\beta_{1} M F+\beta_{2} T A C C+\beta_{3} S T D \_C F O+\beta_{4} C F O+\beta_{5} R E T+\beta_{6} S I Z E \\
& +\beta_{7} B M+\beta_{8} \text { LEVERAGE }+\beta_{9} \mathrm{NUM} \_\mathrm{ANAL}+\beta_{10} \mathrm{INSTPCT}+ \\
& \sum I N D T+\sum Y E A R
\end{aligned}
$$

Stock return volatility $(V O L)$ is the average daily variance of marketadjusted returns over various measurement windows, where market-adjusted returns is measured as the excess of daily stock return for firm $i$ over the CRSP value-weighted index return (Rajgopal \& Venkatachalam, 2011). Figure 1 presents the variable measurement timeline. 


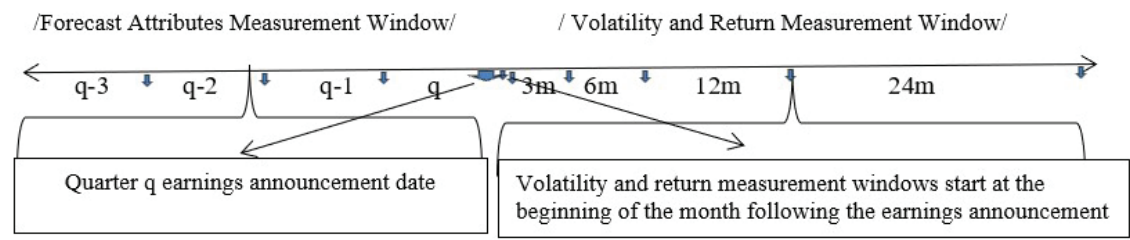

Figure 1: Measurement Timeline

The variable of interest, $M F$, is an indicator variable taking the value of 1 if firm $i$ issues earnings per share forecast (EPS) for quarter $q$ and taking the value of zero otherwise. $M F$ is expected to be negatively associated with stock return volatility. Several factors that are poised to influence stock return volatility. Prior studies showed that firm-level stock returns are a function of cash flow news, implying a positive relation between stock return volatility and cash flow volatility. Cash flow volatility $\left(S T D \_C F O\right)$ is measured by the standard deviation of quarterly operating cash flows over the past eight quarters. Existing research documents that both operating performance and stock performance exhibit a negative relation with stock return volatility. Thus, the model included both performance measures. Specifically, operating performance $(C F O)$ was measured by quarterly operating cash flows scaled by total assets; stock return is the raw return over various measurement windows, as discussed in the preceding sections. Large firms are more likely to operate in a stable economic environment and to operate at a stable stage along the firm's life cycle. Consequently, firm size should bear a negative relation with stock return volatility. Firm size (SIZE) was measured by total assets.

As financial reporting processes are probably still evolving, high growth firms could exhibit greater information risks, indicating greater information uncertainty and more volatile stock returns. As high growth firms are at the rapid expansion stage of a firm's life cycle, historical financial performance could be a poor indicator of future performance, which could be another source of information uncertainty. Book-to-market ratio (BM) is used to measure a firm's growth opportunities, which is expected to bear a negative relation between $B M$ and stock return volatility. Highly leveraged firms are more likely to experience financial distress. The extent of uncertainty about prospects is also greater for highly leveraged firms. Leverage (LEVERAGE) is measured as the ratio of total liabilities to total assets. 
Rajagopal and Venkatachalam (2011) document a positive link between earnings quality and stock returns volatility. As poor earnings quality is less revealing about firms' economic prospects, the extent of information uncertainty should be higher for firms exhibiting poor earnings quality. Earnings quality is measured by the magnitude of total accruals $(T A C C)$. As poor earnings quality could be attributable to innate economic factors (i.e., business models) or attributable to earnings management, Total accruals $(T A C C)$ is viewed as an appropriate measure in this setting. Financial analysts and institutional investors play an increasingly important role in the capital markets and greatly influence a firm's information environment. On the one hand, the existence of a large number of informed investors should prompt firms to disclose more information and thus reduce information uncertainty and stock return volatility; on the other hand, certain groups of institutional investors may engage in high-frequency trading, thereby exacerbating stock return volatilities. Consequently, the direction of the impact, ex ante, is unclear. The number of analysts following the firm (NUM_ANALYST) and the percentage of institutional ownership (INSTPCT) are included in the model to control the effects of informed investors (Chuk, Matsumoto, \& Miller, 2013).

The first hypothesis tested the effect of the issuance of quarterly earnings forecasts on stock return volatility. The primary focus of this study, however, was to examine whether "superior" short-term earnings guidance benefits issuers and investors in the form of reduced stock return volatility. Superior guidance issuers were identified based on four forecast attributes: accuracy ( $A C C U R A C Y)$, regularity (REGULARITY), timeliness (TIMELINESS), and consistency in delivery of earnings (CONSISTENCY).

$$
\begin{aligned}
\mathrm{VOL}= & \beta_{0}+\beta_{r} A C C U R A C Y+\beta_{2} \text { TACC }+\beta_{3} S T D_{-} C F O+\beta_{4} C F O+\beta_{5} R E T \\
& +\beta_{6} \text { SIZE }+\beta_{7} B M+\beta_{8} \text { LEVERAGE }+\beta_{9} \mathrm{NUM} \text { _ANALYST }+ \\
& \beta_{10} \text { INSTPCT }+\sum I N D T+\sum Y E A R
\end{aligned}
$$

$$
\begin{aligned}
\mathrm{VOL}= & \beta_{0}+\beta_{1} R E G U L A R I T Y+\beta_{2} \text { TACC }+\beta_{3} S T D_{-} C F O+\beta_{4} C F O+ \\
& \beta_{5} R E T+\beta_{6} S I Z E+\beta_{7} B M+\beta_{8} \text { LEVERAGE }+\beta_{9} \mathrm{NUM} \text { _ANALYST } \\
& +\beta_{10} \mathrm{INSTPCT}+\sum I N D T+\sum \text { YEAR }
\end{aligned}
$$

$$
\begin{aligned}
\mathrm{VOL}= & \beta_{0}+\beta_{l} \text { CONSISTENCY }+\beta_{2} \text { TACC }+\beta_{3} S T D_{-} C F O+\beta_{4} C F O+ \\
& \beta_{5} R E T+\beta_{6} S I Z E+\beta_{7} B M+\beta_{8} \text { LEVERAGE }+\beta_{9} \mathrm{NUM} \text { _ANALYST } \\
& +\beta_{10} \mathrm{INSTPCT}+\sum I N D T+\sum \text { YEAR }
\end{aligned}
$$




$$
\begin{aligned}
\mathrm{VOL}= & \beta_{0}+\beta_{1} \text { TIMELINESS }+\beta_{2} \text { TACC }+\beta_{3} S T D_{-} C F O+\beta_{4} C F O+\beta_{5} R E T \\
& +\beta 6 S I Z E+\beta_{7} B M+\beta_{8} \text { LEVERAGE }+\beta_{9} \mathrm{NUM} \text { ANALYST }+ \\
& \beta_{10} \mathrm{INSTPCT}+\sum I N D T+\sum Y E A R
\end{aligned}
$$

ACCURACY was measured by the average forecast accuracy (unsigned difference between realized earnings and forecasted earnings) over the measurement window of trailing 4 quarters. REGULARITY is measured by the frequency of quarterly management EPS forecast over the measurement window of trailing 4 quarters. CONSISTENCY was measured by the frequency of actual earnings meeting or exceeding management issued earnings per share forecasts over the measurement window of trailing 4 quarters. TIMELINESS was measured by the average forecast timeliness, the days between the first forecast release date and the forecast quarter ending date, over the trailing 4 quarters.

\section{Regression Model for Hypotheses H3 and H4}

Regression specification (6), which was developed based on Ohlson's (1995) model and is commonly used in later studies (i.e., Barth, Elliott, \& Finn, 1999), is estimated to test whether guidance issuers achieve higher $\mathrm{P} / \mathrm{E}$ multiples:

$$
\begin{aligned}
\text { PRICE }= & \beta_{0}+\beta_{I} N I+\beta_{2}\left(N I^{*} M F+\beta_{3}\left(N I^{*} B V E G R O W T H\right)+\beta_{4}\left(N I^{*} S T D_{-}\right.\right. \\
& C F O)+\beta_{5}\left(N I^{*} D E\right)+\beta_{6} B V E+\sum I N D T+\sum Y E A R
\end{aligned}
$$

Ohlson's (1995) model relates price to earnings and book value of equity. The cross-sectional variation in price/earnings multiple is affected by firm characteristics such as growth and risks. In model (6), stock price (PRICE) is the price per share at the fiscal quarter end. Earnings per share $(N I)$ is earnings before extraordinary items and discontinued operations. Growth $(B V E G R O W T H)$ is measured as the growth in book value of equity from quarter $q-4$ to quarter $q$. Debt-to-equity ratio $(D E)$ is included in the model to measure financial risks and standard deviation of operating cash flows $\left(S T D \_C F O\right)$ is included to measure operational risks. The primary focus is whether guidance issuers achieve higher $\mathrm{P} / \mathrm{E}$ multiples by lowering information risks through the provision of earnings forecasts. $M F$, an indicator variable as previously defined, is a proxy for information risks. $\mathrm{P} / \mathrm{E}$ multiples increase with firm growth and decrease with firm risks. 
Thus, it is expected to observe a positive incremental effect of guidance on earnings $(\beta 2>0)$.

Models (7) - (10) are estimated to test the association between "superior" management guidance and $\mathrm{P} / \mathrm{E}$ multiples:

$$
\begin{aligned}
\text { PRICE }= & \beta_{0}+\beta_{I} N I+\beta_{2}\left(N I^{*} A C C U R A C Y\right)+\beta_{3}\left(N I^{*} B V E G R O W T H\right)+ \\
& \beta_{4}\left(N I^{*} S T D \_C F O\right)+\beta_{5}\left(N I^{*} D E\right)+\beta_{6} B V E+\sum I N D T+\sum Y E A R
\end{aligned}
$$

PRICE $=\beta_{0}+\beta_{1} N I+\beta_{2}\left(N I^{*} R E G U L A R I T Y\right)+\beta_{3}\left(N I^{*} B V E G R O W T H\right)+$ $\beta_{4}\left(N I * S T D \_C F O\right)+\beta_{5}(N I * D E)+\beta_{6} B V E+\sum I N D T+\sum Y E A R$

PRICE $=\beta_{0}+\beta_{I} N I+\beta_{2}(N I * C O N S I S T E N C Y)+\beta_{3}(N I * B V E G R O W T H)+$ $\beta_{4}\left(N I * S T D \_C F O\right)+\beta_{5}(N I * D E)+\beta_{6} B V E+\sum I N D T+\sum Y E A R$

PRICE $=\beta_{0}+\beta_{I} N I+\beta_{2}(N I *$ TIMELINESS $)+\beta_{3}(N I * B V E G R O W T H)+$ $\beta_{4}\left(N I * S T D \_C F O\right)+\beta_{5}(N I * D E)+\beta_{6} B V E+\sum I N D T+\sum Y E A R$

\section{RESULTS AND DISCUSSION}

\section{Guidance and Stock Return Volatility (H1 and H2)}

Table 2: Issuance of Management Earnings

\begin{tabular}{|c|c|c|c|c|}
\hline & \multicolumn{2}{|c|}{ Dependent Variable=VOL3M } & \multicolumn{2}{|c|}{ Dependent Variable=VOL6M } \\
\hline INTERCEPT & 0.0326 & $<0.001^{* * *}$ & 0.0314 & $0.000^{* * *}$ \\
\hline MF & -0.0007 & $0.003^{*+* *}$ & -0.0005 & $0.034^{* * *}$ \\
\hline TACC & 0.0410 & $<0.001^{* * *}$ & 0.0411 & $<0.001^{* \star *}$ \\
\hline STD_CFO & 0.0327 & $<0.001^{* * *}$ & 0.0351 & $<0.001^{* \star *}$ \\
\hline CFO & -0.0276 & $<0.001^{* * *}$ & -0.0300 & $<0.001^{* \star *}$ \\
\hline RET3M & -0.0010 & $0.029^{* * *}$ & & \\
\hline RET6M & & & -.0012 & $<0.001^{* * *}$ \\
\hline SIZE & -0.0002 & $<0.001^{\star \star \star *}$ & -0.0002 & $<0.001^{* \star *}$ \\
\hline BM & 0.0052 & $<0.001^{* * *}$ & 0.0052 & $<0.001^{* * *}$ \\
\hline LEVERAGE & -0.0036 & $<0.001^{\star \star \star}$ & -0.0034 & $<0.001^{\star \star \star}$ \\
\hline
\end{tabular}
Guidance and Stock Return Volatility 


$\begin{array}{lcccc}\text { NUM_ANAL } & -0.0009 & <0.001^{*+*} & -0.0009 & <0.001^{*+*+} \\ \text { INSTPCT } & -0.0072 & <0.001^{*+*+} & -0.0071 & <0.001^{\text {*n+* }} \\ \text { INDUSTRY } & \text { Yes } & & \text { Yes } & \\ \text { YEAR } & \text { Yes } & & \text { Yes } & \\ \text { Observations } & 31,648 & & 31,648 & \\ \text { Adj. R } & 0.377 & & 0.417 & \end{array}$

Standard errors are clustered at firm level. $P$ values in italics. ${ }^{* * *},{ }^{* *}$, and ${ }^{*}$ indicate statistical significance at $1 \%, 5 \%$, and $10 \%$ using two-tailed test, respectively

Table 2 presents the results from estimating equation (1). Panel A shows that guidance issuers appeared to have less volatile stock returns over the 3-month measurement window $(p<0.01)$. Thus, the issuance of shortterm earnings guidance seemed to reduce information uncertainty. Table 2 also shows that firms with inferior earnings quality exhibited increased stock price volatility $(p<0.01)$. Not surprisingly, large and profitable firms that operate in stable environments exhibited decreased return volatility. Furthermore, Table 2 confirms that firms with higher contemporaneous buy-and-hold returns exhibit lower price volatility. Inconsistent with the predictions, firms with higher growth and higher leverage exhibited lower return volatility. Finally, the coefficients on analyst following and institutional investors were both significantly negative, suggesting that informed investors play important roles in shaping information environments and reducing information risks. Results are similar when stock return volatility was measured over the 6-month window. Untabulated results show the relation between the provision of short-term guidance and stock return volatility over longer horizons (12- and 24-month). The coefficients on MF were negative but statistically insignificant in both the 12- and 24-month specifications, indicating that the provision of a quarterly earnings guidance was not effective in reducing information uncertainty over longer horizon. 
Table 3: Quality of Management Earnings

Guidance and Stock Return Volubility

Panel A: Test of the Association Between Forecast Attributes and Short-Window Stock Return Volatility

\begin{tabular}{|c|c|c|c|c|}
\hline \multirow[b]{2}{*}{ INTERCEPT } & \multicolumn{4}{|c|}{ Dependent Variable $=$ VOL3M } \\
\hline & 0.0363 & 0.0363 & 0.0373 & 0.0372 \\
\hline & $<0.001^{* * *}$ & $<0.001^{* * *}$ & $<0.001^{* * *}$ & $<0.001^{* * *}$ \\
\hline ACCURACY & -0.0010 & & & \\
\hline REGULARITY & & -0.0009 & & \\
\hline CONSISTENCY & & & -0.0006 & \\
\hline \multirow[t]{2}{*}{ TIMELINESS } & & & & -0.0022 \\
\hline & $<0.001^{* * *}$ & $<0.001^{* * *}$ & $0.069^{*}$ & $0.071^{*}$ \\
\hline \multirow[t]{2}{*}{ TACC } & 0.0402 & 0.0409 & 0.0410 & 0.0410 \\
\hline & $<0.001^{* \star *}$ & $<0.001^{* * *}$ & $<0.001^{* * *}$ & $<0.001^{* * *}$ \\
\hline \multirow[t]{2}{*}{ STD_CFO } & 0.0470 & 0.0459 & 0.0470 & 0.0470 \\
\hline & $<0.001^{* * *}$ & $<0.001^{* * *}$ & $<0.001^{* * *}$ & $<0.001^{* * *}$ \\
\hline \multirow[t]{2}{*}{ CFO } & -0.0294 & -0.0290 & -0.0299 & -0.0030 \\
\hline & $<0.001^{* \star *}$ & $<0.001^{* * *}$ & $<0.001^{* * *}$ & $<0.001^{* * t}$ \\
\hline \multirow[t]{2}{*}{ RET3M } & -0.0016 & -0.0015 & -0.0015 & -0.0015 \\
\hline & $0.007^{* * *}$ & $0.011^{* * *}$ & $0.010^{* * *}$ & $0.013^{\text {tw+ }}$ \\
\hline \multirow[t]{2}{*}{ SIZE } & -0.0002 & -0.0002 & -0.0002 & -0.0002 \\
\hline & $<0.001^{* \star *}$ & $<0.001^{* * *}$ & $<0.001^{* * *}$ & $<0.001^{* * *}$ \\
\hline \multirow[t]{2}{*}{ BM } & 0.0040 & 0.0041 & 0.0041 & 0.0041 \\
\hline & $<0.001^{* \star *}$ & $<0.001^{* * * *}$ & $<0.001^{* * *}$ & $<0.001^{* * t}$ \\
\hline \multirow[t]{2}{*}{ LEVERAGE } & -0.0056 & -0.0055 & -0.0056 & -0.0056 \\
\hline & $<0.001^{* \star *}$ & $<0.001^{* * *}$ & $<0.001^{* * *}$ & $<0.001^{* * t}$ \\
\hline \multirow[t]{2}{*}{ NUM_ANAL } & -0.0011 & -0.0010 & -0.0010 & -0.0012 \\
\hline & $<0.001^{* \star *}$ & $<0.001^{* * * *}$ & $<0.001^{* * *}$ & $<0.001^{* * t}$ \\
\hline \multirow[t]{2}{*}{ INSTPCT } & -0.0084 & -0.0081 & -0.0085 & -0.0084 \\
\hline & $<0.001^{* * * t}$ & $<0.001^{*+* t}$ & $<0.001^{* * *+}$ & $<0.001^{*+* x}$ \\
\hline INDUSTRY & Yes & Yes & Yes & Yes \\
\hline YEAR & Yes & Yes & Yes & Yes \\
\hline Adj. $R^{2}$ & 0.4040 & 0.4055 & 0.4019 & 0.4018 \\
\hline Observations & 15,816 & 15,816 & 15,816 & 15,816 \\
\hline
\end{tabular}

Standard errors are clustered at firm level. $P$ values in italics. ${ }^{* \star *},{ }^{* *}$, and ${ }^{*}$ indicate statistical significance at $1 \%, 5 \%$, and $10 \%$ using two-tailed test, respectively 
The second set of tests (H2) examined whether and how "superior" guidance issuers achieve the benefits of reduced price volatility. Results from estimating equations (2) - (5) are presented in Table 3. As shown in Panel A, the effects of "superior" management earnings forecasts on short-term stock return volatility measured over three-month window. "Superiority" was operationalized by accuracy, regularity, consistency, and timeliness, respectively. Across each of the four regression specifications, "superior" guiders exhibited reduced stock return volatility. The first specification showed that the coefficient on $A C C U R A C Y$ was negative and statistically significant $(\beta 1=-0.0010 ; p<0.01)$, which indicated that firms with a track record of providing more accurate quarterly earnings forecasts experienced lower return volatility over the short measurement window. The significant negative coefficient on TIMELINESS $(\beta 1=-0.0022 ; p=0.07)$ suggested that firms who release management guidance earlier in the financial reporting cycle were deemed as possessing less information uncertainty. Similarly, specification (2) and specification (3) show that regular guiders with a track record of delivering earnings (meeting or beating their own forecasted quarterly EPS) were perceived as less risky than those that provided sporadic forecasts or fail to meet their own guided numbers. Untabulated results showed that superior guidance issuers exhibited similar reduced stock return volatility over the 6-month measurement window.

Table 3: Quality of Management Earnings Guidance and Stock Return Volatility

\begin{tabular}{|c|c|c|c|c|}
\hline \multicolumn{5}{|c|}{$\begin{array}{l}\text { Panel B: Test of the Association between Forecast Attributes and Long-Window } \\
\text { Stock Return Volatility }\end{array}$} \\
\hline & \multicolumn{4}{|c|}{ Dependent Variable = VOL12M } \\
\hline \multirow[t]{2}{*}{ INTERCEPT } & 0.0360 & 0.0364 & 0.0374 & 0.0372 \\
\hline & $<0.001^{* \star \star}$ & $<0.001^{*+*}$ & $<0.001^{* * *}$ & $<0.001^{* \star *}$ \\
\hline ACCURACY & -0.0011 & & & \\
\hline REGULARITY & & -0.0007 & & \\
\hline CONSISTENCY & & & -0.0010 & \\
\hline \multirow[t]{2}{*}{ TIMELINESS } & & & & -0.0028 \\
\hline & $<0.001^{* * *}$ & $<0.001^{* * *}$ & $0.007^{* *}$ & $0.026^{* *}$ \\
\hline \multirow[t]{2}{*}{ TACC } & 0.0428 & 0.0438 & 0.0435 & 0.0438 \\
\hline & $<0.001^{* \star *}$ & $<0.001^{* * *}$ & $<0.001^{* * *}$ & $<0.001^{* * *}$ \\
\hline \multirow[t]{2}{*}{ STD_CFO } & 0.0467 & 0.0457 & 0.0467 & 0.0467 \\
\hline & $<0.001^{* * *}$ & $<0.001^{*+* t}$ & $<0.001^{* * *}$ & $<0.001^{* \star *}$ \\
\hline
\end{tabular}




\begin{tabular}{|c|c|c|c|c|}
\hline \multirow[t]{2}{*}{ CFO } & -0.0336 & -0.0336 & -0.0342 & -0.0343 \\
\hline & $<0.001^{* \star *}$ & $<0.001^{*+*}$ & $<0.001^{* * *}$ & $<0.001^{* * *}$ \\
\hline \multirow[t]{2}{*}{ RET12M } & -0.0016 & -0.0015 & -0.0015 & -0.0015 \\
\hline & $<0.001^{* * *}$ & $<0.001^{* * *}$ & $<0.001^{* * *}$ & $<0.001^{\text {**** }}$ \\
\hline \multirow[t]{2}{*}{ SIZE } & -0.0002 & -0.0002 & -0.0002 & -0.0002 \\
\hline & $<0.001^{* * *}$ & $<0.001^{* * *}$ & $<0.001^{* * *}$ & $<0.001^{* * *}$ \\
\hline \multirow[t]{2}{*}{ BM } & 0.0045 & 0.0047 & 0.0047 & 0.0047 \\
\hline & $<0.001^{* * *}$ & $<0.001^{* * *}$ & $<0.001^{* * *}$ & $<0.001^{* * *}$ \\
\hline \multirow[t]{2}{*}{ LEVERAGE } & -0.0048 & -0.0012 & -0.0048 & -0.0048 \\
\hline & $<0.001^{* * *}$ & $<0.001^{* \star *}$ & $<0.001^{* * *}$ & $<0.001^{* * *}$ \\
\hline \multirow[t]{2}{*}{ NUM_ANAL } & -0.0013 & -0.0079 & -0.0013 & -0.0013 \\
\hline & $<0.001^{* * *}$ & $<0.001^{* * *}$ & $<0.001^{* * *}$ & $<0.001^{* * *}$ \\
\hline \multirow[t]{2}{*}{ INSTPCT } & -0.0081 & -0.0079 & -0.0083 & -0.0081 \\
\hline & $<0.001^{* * *}$ & $<0.001^{* * *}$ & $<0.001^{* * *}$ & $<0.001^{* * *}$ \\
\hline INDUSTRY & Yes & Yes & Yes & Yes \\
\hline YEAR & Yes & Yes & Yes & Yes \\
\hline Adj. $R^{2}$ & 0.4372 & 0.4357 & 0.4338 & 0.4333 \\
\hline Observations & 15,816 & 15,816 & 15,816 & 15,816 \\
\hline
\end{tabular}

Standard errors are clustered at firm level. $P$ values in italics. ${ }^{* * *},{ }^{* *}$, and ${ }^{*}$ indicate statistical significance at $1 \%, 5 \%$, and $10 \%$ using two-tailed test, respectively.

Next, this study examined whether the benefit of reduced stock price volatility accrued to superior guiders extends to longer measurement windows. Panel B reports the estimated results from equations (2) - (5), where stock return volatility was measured over the 12-month window. Across each of the four columns, Panel B showed consistent evidence that superior guiders exhibited lower stock return volatility. Results were qualitatively similar when stock return volatility was measured over the 24-month measurement window. In sum, the study found evidence consistent with the second prediction: firms that have developed superior guidance practice exhibited reduced stock return volatility. For average firms, the benefit of reduced volatility appeared to be short run; the benefit accrued to superior guiders seemed to be more permanent. 


\section{Guidance and Valuation (H3 and H4)}

Table 4: Issuance of Management Earnings Guidance and P/E Multiples

\begin{tabular}{lcc}
\hline & \multicolumn{2}{c}{ Dependent Variable = PRICE } \\
\hline INTERCEPT & Coeff. & $p$-value \\
$\mathrm{NI}$ & 13.575 & 0.145 \\
$\mathrm{NI}{ }^{*}$ MF & 20.274 & $<0.001^{* * *}$ \\
$\mathrm{NI}{ }^{*}$ GROWTH & $\mathbf{1 . 2 9 7}$ & $\mathbf{0 . 1 5 6}$ \\
$\mathrm{NI}{ }^{*}$ STD_CFO & 0.608 & 0.335 \\
$\mathrm{NI}{ }^{*}$ DE & 64.367 & $<0.001^{* * *}$ \\
BVE & -0.386 & 0.564 \\
& 0.831 & $<0.001^{* * *}$ \\
INDUSTRY & & \\
YEAR & Yes & \\
Adj. R & Yes & \\
Observations & 0.5962 & \\
\hline
\end{tabular}

Standard errors are clustered at firm level. $P$ values in italics. ${ }^{* * *},{ }^{* *}$, and ${ }^{*}$ indicate statistical significance at $1 \%, 5 \%$, and $10 \%$ using two-tailed test, respectively.

The third test examined whether firms issuing short-term earnings guidance received price premium, a belief held by many guidance issuers. Table 4 presents the estimation results of equation (6). Table 4 revealed a positive coefficient on the interaction term NI*MF; however, it is not statistically significant $(\beta 2=1.297, p=0.156)$. Thus, there is little support for the belief that firms issuing quarterly earnings' guidance receive a price premium due to lower information risks. Turning to other variables, Table 4 shows statistically significant positive coefficient on $N I(\beta 2=20.274, p<0.01)$ and $B V E(\beta 6=0.831, p<0.01)$. For most interaction terms, the coefficients had expected signs but were not statistically significant. Inconsistent with the prediction that firms with higher operational risks are valued less by investors, Table 4 reveals a statistically significant positive coefficient on $N I^{*} S T D \_C F O$, where $S T D \_C F O$ was a proxy for operational risks. 
Table 5: Quality of Management Earnings Guidance and P/E Multiples

\begin{tabular}{|c|c|c|c|c|}
\hline \multirow[b]{2}{*}{ INTERCEPT } & \multicolumn{4}{|c|}{ Dependent Variable = PRICE } \\
\hline & 35.752 & 4.8570 & 35.350 & 36.3698 \\
\hline & $<0.001^{* * *}$ & $0.004^{* * *}$ & $0.019^{* *}$ & $<0.001^{* * *}$ \\
\hline \multirow[t]{2}{*}{$\mathrm{NI}$} & 20.593 & 14.348 & 20.870 & 17.313 \\
\hline & $<0.001^{* \star *}$ & $<0.001^{* \star \star}$ & $<0.001^{* \star \star}$ & $<0.001^{* \star *}$ \\
\hline \multirow[t]{2}{*}{ NI*ACCURACY } & 1.189 & & & \\
\hline & $0.081^{*}$ & & & \\
\hline \multirow[t]{2}{*}{ NI*REGULARITY } & & 1.768 & & \\
\hline & & $<0.001^{* \star *}$ & & \\
\hline \multirow[t]{2}{*}{ NI*CONSISTENCY } & & & -1.707 & \\
\hline & & & 0.194 & \\
\hline \multirow[t]{2}{*}{ NI*TIMELINESS } & & & & 13.827 \\
\hline & & & & $0.006^{\star \star *}$ \\
\hline \multirow[t]{2}{*}{ NI*GROWTH } & 1.056 & 1.113 & 0.902 & 1.0430 \\
\hline & 0.241 & 0.206 & 0.318 & 0.243 \\
\hline \multirow[t]{2}{*}{ NI*STD_CFO } & 92.1050 & 91.518 & 94.749 & 88.9476 \\
\hline & $<0.001^{* * *}$ & $<0.001^{* \star *}$ & $<0.001^{\star \star *}$ & $<0.001^{* \star *}$ \\
\hline \multirow[t]{2}{*}{$N I^{*} \mathrm{DE}$} & -0.839 & -0.882 & -0.899 & -0.7982 \\
\hline & 0.263 & 0.234 & 0.232 & 0.284 \\
\hline \multirow[t]{2}{*}{ BVE } & 0.890 & 0.882 & 0.880 & 0.8882 \\
\hline & $<0.001^{* \star *}$ & $<0.001^{* \star \star}$ & $<0.001^{* * *}$ & $<0.001^{* * *}$ \\
\hline INDUSTRY & Yes & Yes & Yes & Yes \\
\hline YEAR & Yes & Yes & Yes & Yes \\
\hline Adj. $R^{2}$ & 0.6242 & 0.6259 & 0.6240 & 0.6248 \\
\hline Observations & 15,818 & 15,818 & 15,818 & 15,818 \\
\hline
\end{tabular}

Standard errors are clustered at firm level. $P$ values in italics. ${ }^{* * *},{ }^{* *}$, and ${ }^{*}$ indicate statistical significance at $1 \%, 5 \%$, and $10 \%$ using two-tailed test, respectively.

The last set of tests examined whether investors place a value premium on firms that provide "superior" management earnings forecast (H4). Table 5 presents results from estimating equations (7)- (10). Table 5 shows statistically significant positive coefficients on $N I^{*} A C C U R A C Y(\beta 2=1.189$, $p=0.08), N I^{*} R E G U L A R I T Y(\beta 2=1.768, p<0.01)$, and $N I^{*}$ TIMELINESS $(\beta 2$ $=13.827, p<0.01)$. These results suggested that firms with a track record of issuing accurate and timely earnings guidance on a regular basis were 
indeed rewarded by investors. However, there is little evidence that firms consistently delivering their earnings received price premiums. In sum, the last set of analysis suggested that firms did not receive market rewards in the form of higher $\mathrm{P} / \mathrm{E}$ multiples by merely issuing short-term earnings guidance. Firms with an established track record of issuing accurate and timely quarterly earnings guidance were perceived as possessing less information risks and thus received higher market valuation relative to other guidance issuers.

\section{CONCLUSION}

This study examined whether capital markets reward the practice of issuing quarterly management earnings forecasts. Despite the widespread criticism that short-term earnings guidance shifts managerial attention away from long-term business development and encourages earnings management, a significant number of firms still followed the practice of providing earnings forecasts on a quarter-by-quarter basis. Limited academic research investigating the costs and benefits of issuing short-term earnings guidance has yielded contradictory results.

Using a sample of quarterly earnings guidance issued by U.S. publicly traded companies, this study documents that firms issuing short-term earnings guidance experience a temporary reduction (one- to two-quarter) in stock price volatility. There is no evidence that the short-term guidance issuers were valued more favorably by capital markets. Furthermore, this study found that firms with a track record of regularly supplying accurate and timely management earnings forecasts were indeed rewarded by capital markets in the form of reduced stock return volatility, and this benefit was more permanent. The last set of results showed that not all short-term guidance issuers were valued favorably by investors. "Superior" forecasters who provide accurate and timely short-term earnings guidance on a regular basis exhibited higher $\mathrm{P} / \mathrm{E}$ multiples than other guidance issuers.

Overall, findings in this study support the view that superior guidance issuers benefit from the practice of issuing quarterly earnings forecasts, which fosters transparent information environments and reduces investor information uncertainty. These findings also provide insights into corporate 
voluntary disclosure practice, which should be of interest to corporate managers who aim to improve investor communications through highquality voluntary disclosures. Lastly, this study provides an explanation for corporate managers' forecast choices (e.g., accuracy and horizon), an area less developed in the management earnings forecast literature. Specifically, this study suggests that superior guidance issuers derive significant capital market benefits by issuing accurate and timely management earnings forecasts on a regular basis.

This study is subject to two potential limitations. The sample was drawn from the CIG database over 2001-2009, the most recent period when CIG data was available. If subsequent regulations have significantly changed corporate disclosures, investor composition, or investor trading behavior, a new study on the benefits of management earnings forecasts is warranted. Furthermore, Chuck, Matsumoto, and Miller (2013) documented systematic differences between forecasts reported on CIG and forecasts gathered from company press releases. They noted that the probability of a firm being covered by CIG was greater for firms with high analyst following and high institutional ownership, and lower for firms reporting losses in the recent past. We may observe different results if the sample firms are drawn from another source (e.g., press releases) to study the capital market benefits of superior quarterly earnings guidance.

\section{REFERENCES}

Atiase, R., Li, H., Supattarakul, S., \& Tse, S. (2005). Market reaction to multiple contemporaneous earnings signals: Earnings announcements and future earnings guidance. Review of Accounting Studies, 50, $497-$ 525 .

Baginski, S. P., \& Rakow, K. C. (2012). Management earnings forecast disclosure policy and the cost of equity capital. Review of Accounting Studies, 17, 279-321.

Barth, M., Elliott, J., \& Finn, M. (1999). Market rewards associated with patterns of increasing earnings. Journal of Accounting Research, 37, 387-413. 
Beach, L. R., Mitchell, T. R., Deaton, M. D., \& Prothero, J. (1978). Information relevance, content, and source credibility in the revision of opinions. Organizational Behavior and Human Performance, February, $1-16$.

Birnbaum, M., Wong, R., \& Wong, L. K. (1976). Combining information from sources that vary in credibility. Memory and Cognition, 330-336.

Call, A., Chen, S., Miao, B. \& Tong, Y. (2014). Short-term earnings guidance and accrual-based earnings management. Review of Accounting Studies, 19, 955-987.

Campbell, J. Y., Lettau, M., Malkiel, B. G., \& Xu, Y. (2001). Have individual stocks become more volatile? An empirical exploration of idiosyncratic risk. Journal of Finance, 56, 1-43.

Cao, Y., Myers, L., Tsang, A., \& Yang, Y. (2017). Management forecasts and the cost of equity capital: International evidence. Review of Accounting Studies, 22, 791-838.

Chen, S., Matsumoto, D., \& Rajgopal, S. (2011). Is silence golden? An empirical analysis of firms that stop giving quarterly earnings guidance. Journal of Accounting \& Economics, 51, 134-150.

Chuk, E., Matsumoto, D., \& Miller, G. (2013). Assessing methods of identifying management forecasts: CIG vs. researcher collected. Journal of Accounting \& Economics, 55, 23-42.

Deloitte. (2009). Earnings guidance: The current state of play. Available for purchase at: http://www.financialexecutive.org.

Feng, M., Li, C., \& McVay, S. (2009). Internal control and management guidance. Journal of Accounting \& Economics, 48, 190-209.

Goodman, T., Neamtiu, M., Shroff, N., \& White, H. (2014). Management forecast quality and capital investment decisions. The Accounting Review, 89, 331-365. 
Graham, J., Harvey, C., \& Rajgopal, S. (2005). The economic implications of corporate financial reporting. Journal of Accounting \& Economics, $40,3-73$.

Guan, Y., Lobo, G., Tsang, A., \& Xin, X. (2021). Social trust and management earnings forecast. The Accounting Review, 95, 149-184.

Higashikawa, K. (2021). Earnings quality and earnings forecasts based on a cross-sectional model. Asia-Pacific Management Accounting Journal, $15,141-163$.

Hilary, G., Hsu, C., Segal, B., \& Wang, R. (2016). The bright side of managerial over-optimism. Journal of Accounting \& Economics, 62, 46-64.

Hinsz, V., Tindale, R., Nagao, D., Davis, J., \& Robertson, B. (1998). The influence of the accuracy of individuating information on the use of base rate information in probability judgment. Journal of Experimental Social Psychology, 27-45.

Hirst, E., Koonce, L, \& Miller, J. (1999). The joint effect of management's prior forecast accuracy and the form of its financial forecasts on investor judgment. Journal of Accounting Research, 37, 101-124.

Hirst, E., Koonce, L., \& Venkataraman, S. (2008). Management earnings forecasts: a review and framework. Accounting Horizons, 22, 315-338.

Houston J., Lev, B., \& Tucker, J. (2010). To guide or not to guide? Causes and consequences of stopping quarterly earnings guidance. Contemporary Accounting Research, 27, 143-185.

Hutton, A., \& Stocken, P. (2009). Prior forecasting accuracy and investor reaction to management earnings forecasts (Working Paper, Boston College).

Hutton, A., Marcus, A., \& Tehranian, H. (2009). Opaque financial reports, R-square, and crash risk. Journal of Financial Economics, 94, 67-86. 
Jin, L., \& Myers, S. (2006). R-squared around the world: New theory and new tests. Journal of Financial Economics, 79, 257-292.

Kahneman, D., \& Tversky, A. (1982). Variants of uncertainty. Cognition, 143-157.

Kato, K., Skinner, D., \& Kunimura, M. (2009). Management forecasts in Japan: an empirical study of forecasts that are effectively mandated. The Accounting Review, 84, 1575-1606.

Kim, J., Kim, Y., \& Lee, J. (2021). Analyst reputation and management earnings forecasts. Journal of Accounting and Public Policy, forthcoming.

Kim, Y., Su, L., \& Zhu., X. (2016). Does the cessation of quarterly earnings guidance reduce investors' short-termism? Review of Accounting Studies, 22, 715-752.

Li, W., Ng, J., Tsang, A., \& Urcan, O. (2021). Country-level institutions and management earnings forecasts. The Accounting Review, 95, 149-184.

Mock, R., Yeung, B., \& Yu, W. (2000). The information content of stock markets: Why do emerging markets have synchronous stock price movements? Journal of Financial Economics, 58, 215-260.

Ohlson, J. (1995). Earnings, book value and dividends in security valuation. Contemporary Accounting Research, Spring 1995, 662-687.

Rajgopal, S., \& Venkatachalam, M. (2011). Financial reporting quality and idiosyncratic volatility over the last four decades. Journal of Accounting \& Economics, 51, 1-20.

Settle, R., \& Golden, L. (1974). Attribution theory and advertiser credibility. Journal of Marketing Research, 181-185.

Trueman, B. (1986). Why do managers voluntarily release earnings forecasts? Journal of Accounting \& Economics, 8, 53-71. 
Waymire, G. (1985). Earnings volatility and voluntary management forecast disclosure. Journal of Accounting Research, 23, 268-295.

Williams, P. A. (1996). The relation between prior earnings forecast by management and analyst response to a current management forecast. The Accounting Review, 71, 103-115.

Yang, H. (2012). Capital market consequences of managers' voluntary disclosure styles. Journal of Accounting \& Economics, 53, 167-184.

Yasukata, K. (2013). Management Forecasts in Japan: Do managers accurately estimate costs when they issue management forecasts? Journal of Cost Management, Japan, 2, 13-29. 


\section{APPENDIX}

\begin{tabular}{|c|c|}
\hline Variable & Definition \\
\hline MF & $\begin{array}{l}\text { An indicator variable, takes the value of one if firm } \mathrm{i} \text { issues quarterly } \\
\text { earnings forecast for quarter } q \text { and zero otherwise. }\end{array}$ \\
\hline TACC & $\begin{array}{l}\text { The absolute value of total accruals. CFO is operating cash flows } \\
\text { scaled by beginning total assets. }\end{array}$ \\
\hline STD_CFO & $\begin{array}{l}\text { The standard deviation of operating cash flows scaled by beginning } \\
\text { total assets over the trailing } 8 \text { quarters. }\end{array}$ \\
\hline SIZE & The book value of total assets. \\
\hline BM & book-to-market ratio. \\
\hline LEVERAGE & The ratio of total liabilities to total assets. \\
\hline NUM_ANAL & $\begin{array}{l}\text { The number of analysts contributing quarterly consensus EPS } \\
\text { forecasts recorded in the first-call database. }\end{array}$ \\
\hline INSTPCT & $\begin{array}{l}\text { The average percentage of institutional ownership during the fiscal } \\
\text { year. }\end{array}$ \\
\hline $\mathrm{NI}$ & $\begin{array}{l}\text { net income per share before extraordinary items and discontinued } \\
\text { operations. }\end{array}$ \\
\hline BVE & book value of equity per share. \\
\hline BVEGROWTH & growth in book value of equity from quarter q-4 to quarter q. \\
\hline $\mathrm{DE}$ & debt to equity ratio. \\
\hline RET & $\begin{array}{l}\text { RET3M, RET6M, RET12M, and RET24, are buy and hold returns } \\
\text { over the 3-month, 6-month, 12-month, and } 24 \text {-month measurement } \\
\text { windows. }\end{array}$ \\
\hline VOL & $\begin{array}{l}\text { Vol3M, Vol6M, Vol12M, and Vol24M are variance of market adjusted } \\
\text { returns over the } 3 \text {-month, } 6 \text {-month, } 12 \text {-month, and } 24 \text {-month } \\
\text { measurement windows. Market adjusted returns are the excess of } \\
\text { daily stock returns over the CRSP value-weighted index returns. }\end{array}$ \\
\hline PRICE & the stock price at the fiscal quarter end. \\
\hline P/E_RATIO & the price to earnings ratio at the end of fiscal quarter q. \\
\hline ACCURACY & $\begin{array}{l}\text { the average forecast accuracy over the measurement window } \\
\text { of trailing } 4 \text { quarters, where forecast accuracy = - |Actual EPS - } \\
\text { Forecasted EPS|/|Actual EPS|; }\end{array}$ \\
\hline REGULARITY & $\begin{array}{l}\text { the frequency of quarterly management EPS forecast over the } \\
\text { measurement window of trailing } 4 \text { quarters. }\end{array}$ \\
\hline CONSISTENCY & $\begin{array}{l}\text { the frequency of actual earnings meeting or exceeding management } \\
\text { issued earnings per share forecasts over the measurement window } \\
\text { of trailing } 4 \text { quarters. }\end{array}$ \\
\hline TIMELINESS & $\begin{array}{l}\text { the average forecast timeliness over the trailing } 4 \text { quarters, where } \\
\text { forecast timeliness = (forecast quarter ending date }- \text { forecast release } \\
\text { date) } / 360 \text {. }\end{array}$ \\
\hline
\end{tabular}

